\title{
Phytosanitary Requirement for Import of Horticulture Crops
}

\author{
Shivani Gupta, Shalini Verma* and Rajneesh Thakur \\ Department of Plant Pathology, Dr. Yaswanth Singh Parmar University of Horticulture and \\ Forestry, Nauni, Solan-173230, India \\ *Corresponding author
}

\section{Keywords}

Exotic pests, Quarantine, Organizations, Phytosanitary measures

\section{Article Info}

Accepted:

20 January 2019

Available Online:

10 February 2019

\section{A B S T R A C T}

The quantum of import and export of plant commodities have been increased during the recent years, there is a distinct possibility of moving insect pests and diseases from their original native habitation to new location. The government of India in 2003 has notification of a new plant Quarantine Order (PQ Order) to harmonized India's regulatory frame work with the International Plant protection Convention (IPPC) and internationally accepted standard and the tenets of the SPS agreement of the World Trade Organization (WTO).Globally, direct yield losses caused by insect-pest and pathogens are altogether responsible for losses ranging between 20 and $40 \%$ of agricultural productivity. There are some important international and national level quarantine diseases which cause extensive damage (about 15-25\%) to our country. So to prevent the introduction of exotic pests, diseases and weeds from foreign countries or within country, there are international agencies like IPPC, and national agencies like NPPO (Directorate of Plant Protection, Quarantine and Storage) which are involved in plant quarantine program. In plant quarantine program, Phytosanitay measures acts as an important tool in excluding pests from the crop. Under Phytosanitary measures, there is requirements needed for exporting as well as importing countries. For exporting countries, Phytosanitary certificate is required for inspection and identification of pest and a requirement for treatment at origin; if required. For importing countries, Acceptance of certification or safeguarding program (involve inspection upon arrival at port of entry or treatment if necessary; isolation, special testing or additional quarantine after entry) at origin. Phytosanitary process for exporting countries involves declaration, document checking, commodities inspection and phytosanitary keeping records whereas phytosanitary process for importing countries involves declaration, checking, inspection of seed plants or benefit organism, regulation of phytosanitary notification, samples and phytosanitary record keeping. More recently, international treaties, like the SPS Agreement and the IPPC have been adopted to provide a framework for how countries should implement national laws and regulations related to managing the risks associated with foreign pests. Thus, phytosanitary measures have become the basis for national laws and regulations aimed at preventing the introduction and spread of new pests. As these quarantine pest causing huge losses to horticultural as well as agricultural commodities, so through the involvement of international and national agencies and by phytosanitary measures, contaminated consignment can be reduce by 40per cent. 


\section{Introduction}

\section{Quarantine}

The term quarantine as French word literally means 40 day period. Quarantine can be defined "as a legal restriction to prevent the entrance and establishment of a plant disease or insect pest in an area where the pest or disease dose no exist". In India plant quarantine is regulated under the destructive insect and pest act, 1914 (Reddy, 2010). The internationally accepted methods require Pest Risk Analysis (PRA) as a defensive method (Rajak et al., 1999).

\section{Importance of plant quarantine}

A number of foreign pests entered subcontinent in the early twenties because of inadequate quarantine control. The significance of plant quarantine has increased in view of globalization and liberalization in international trade of plants and plant material in the wake of Sanitary and Phytosanitary (SPS) Agreement under WTO. Plant quarantine also help to facilitate safe global trade in agriculture by assisting the producers and exporters by providing a reliable Phytosanitary certificate system to meet the requirement of trading partners. It helps to prevent the introduction and spread of exotic pests that are destructive to crops by regulating/restricting the import of plant/plant products. Pathogens of minor consequence in their native environment may be destructive in a new environment. Plant quarantine is vital to prevent the introduction of nonindigenous pests and diseases into a country, or to intercept and eradicate them before they can be widespread and well-established.

\section{History of plant quarantine in India}

The quarantine measures are of almost relevance to a country like India whose economy is largely Agriculture based. The awareness to quarantine measures started in early $20^{\text {th }}$ century when the India government in 1906, ordered compulsory fumigation of imported cotton bales to prevent the introduction of the dreaded Mexican cotton boll weevil. In 1946, the Directorate of plant Protection, Quarantine and Storage, under the ministry of Food and Agriculture were set up at Faridabad. In 1949, the Directorate started its quarantine activities at Bombay seaport. In 1951, the first plant Quarantine and Fumigation station in India was inaugurated. In 1976, the National Bureau of Plant Genetic Resources (NBPGR) was created. In 1978, Division of Plant Quarantine was created with Entomology, Plant Pathology and Nematology section. In 1988, the Plants, Fruits and Seeds (Regulation of import into India) order, 1989 popularly known as PFS order came into force (Laxmi et al., 2014)

\section{Role of plant quarantine in India}

Plant quarantine activities in India are carried out under the Destructive Insects and Pests Act (DIP Act) of 1914 in order to prohibit the import of plants and plant material, insects, fungi and weeds to India from foreign countries(Dent, 1991). The DIP Act empowers the central Government to make rules for regulating the import of planting material into India and also the movement of the materials from one state to another within the country.

\section{Pesticide legislation in India}

Two important central legislation related with pesticides are: (i) The Insecticides Act, 1968.(ii)The Prevention of Food Adulteration Act, 1954. (iii)There are two categories under which legislative measures fall: a) Prevention of entry of exotic diseases and pests into country from abroad and their spread from one state or union territory to other; b) 
Prevention of spread of diseases and pests (including weeds) in localized areas within the state/ Union territory (Atwal and Dhaliwal, 1986; Reddy and Joshi, 1992).

\section{A Plant Quarantine System}

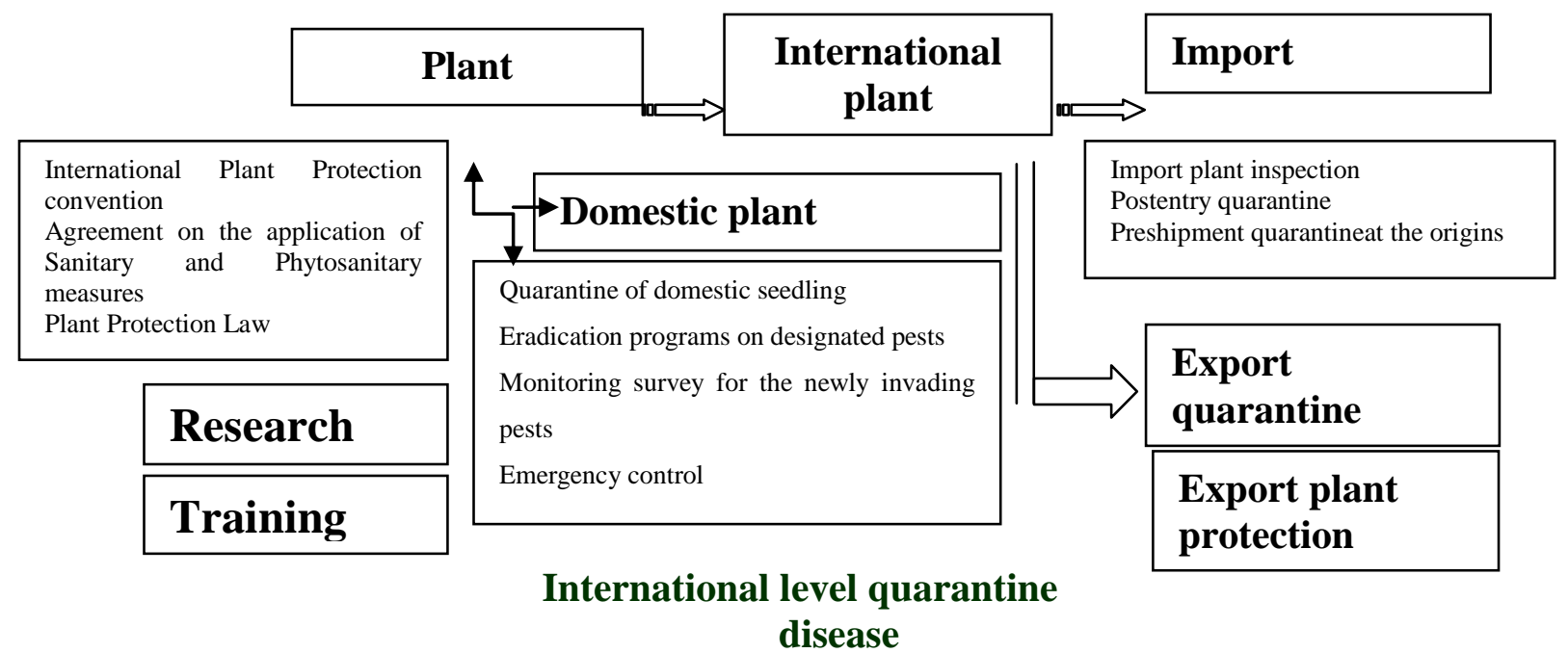

\begin{tabular}{|l|l|l|l|}
\hline Pests & $\begin{array}{l}\text { Introduced } \\
\text { from }\end{array}$ & $\begin{array}{l}\text { Introduced } \\
\text { in }\end{array}$ & Losses caused \\
\hline 1. Powdery mildew of grape (Uncinula necator) & USA & England & $80 \%$ in wine production \\
\hline 2. Downy mildew of grape (Plasmopara viticola) & USA & France & $\$ 50,000$ million \\
\hline 3. Citrus canker (Xantomonas citri) & Asia & USA & $\begin{array}{l}\$ 13 \text { million; 19.5 million } \\
\text { trees destroyed }\end{array}$ \\
\hline 4. Fire blight of apple (Erwinia amylovora) & $\begin{array}{l}\text { North- } \\
\text { America }\end{array}$ & New Zealand & $\$ 100$ million \\
\hline 5. Onion smut (Urocystis cepulae) & France & Switzerland & $42-50 \%$ \\
\hline 6. Coffee rust (Hemilia vastatrix) & $\begin{array}{l}\text { Africa and } \\
\text { Asia }\end{array}$ & Brazil & $30-40 \%$ \\
\hline
\end{tabular}

(Laxmi et al., 2014)

National level quarantine disease

\begin{tabular}{|l|l|l|l|}
\hline Pests & Losses caused & Native place & Year \\
\hline 1. Coffee rust (Hemileiavastatrix) & $\mathbf{3 0 - 4 0 \%}$ & Srilanka & 1879 \\
\hline 2. Late blight of potato (Phytophthorainfestans) & $\mathbf{2 0 \%}$ & England & $\mathbf{1 8 8 3}$ \\
\hline 3. Flag smut of wheat (Urocystistritici) & $\mathbf{3 0 \%}$ & Australia & $\mathbf{1 9 0 6}$ \\
\hline 4. Downy mildew of grapes (Plasmoparaviticola) & $\mathbf{2 0 - 8 0 \%}$ & Europe & $\mathbf{1 9 1 0}$ \\
\hline 5. Downy mildew of cucurbits (P. cubensis) & $\mathbf{5 5 - 7 0 \%}$ & Srilanka & $\mathbf{1 9 1 8}$ \\
\hline 6. Black rot of crucifers (Xanthomonas campestris) & $\mathbf{5 0 \%}$ & Java & $\mathbf{1 9 2 9}$ \\
\hline 7. Crown gall of Apple/pear (Agrobacterium tumefaciens) & $\mathbf{2 0 - 2 5 \%}$ & England & 1940 \\
\hline 8. Bunchy top virus & $\mathbf{6 0 - 7 0 \%}$ & Srilanka & $\mathbf{1 9 4 0}$ \\
\hline 9. Canker of apple (Sphaeropsis spp.) & $\mathbf{3 0 \%}$ in stored fruits & Australia & 1943 \\
\hline 10. Wartof potato (Synchytriumendobioticum) & $\mathbf{2 5 0 0}$ acres infected & Netherlands & $\mathbf{1 9 5 3}$ \\
\hline
\end{tabular}


Terms used in phytosanitary measures (Anonymous, 2017)

\section{Additional declaration}

A statement that is required by an importing country to be entered in Phytosanitary Certificate and which provides specific additional information pertinent to the phytosanitary condition of a consignment.

\section{Authorised Officer}

A technical officer of state/central government organization authorised to issue Plant quarantine clearance.

\section{Biological control agent}

A natural enemy, antagonist, competitor or other organism used for pest control.

\section{Bulbs and Tubers}

A commodity class for dormant underground parts of plant intended for planting (includes corms and rhizomes).

\section{Certificate}

An official document which attests to the phytosanitary status of any consignment affected by phytosanitary regulations.

\section{Commodity}

A type of plant, plant product, or other article being moved for trade or other purpose.

\section{Compliance procedure}

Official procedure used to verify that a consignment complies with stated phytosanitary requirements.

\section{Consignment}

A quantity of plants, plant products and/or other regulated articles being moved from one country to another and covered by a single phytosanitary certificate (a consignment may be composed of one or more lots).

\section{Country of re-Import}

Country into which a consignment of plants, plant products, or other regulated articles have been imported and was stored, split up, had its packaging changed or was otherwise exposed to contamination by pests, prior to a third country.

\section{Cut flowers and branches}

A commodity class for fresh parts of plants intended for decorative use and not for branches planting.

\section{Devitalization}

A procedure rendering plants or plant products incapable of germination, growth or further reproduction.

\section{Dunnage}

Wood packaging material used to secure or support a commodity but which does not remain associated with the commodity.

\section{Field}

A plot of land with defined boundaries within a place of production on which a commodity was grown.

\section{Fruits and vegetables}

A commodity class for fresh parts of plants intended for consumption or processing and not for planting.

\section{Fumigation}

Treatment with a chemical agent that reaches the commodity wholly or primarily in gaseous stage. 


\section{Germplasm}

Plants and plant material intended for use in breeding or conservation programme. Grain: A commodity class for seeds intended for processing or consumption and not for planting.

\section{Import}

An act of bringing into any part or place of territory of Republic of India any kind of seed, plant or plant product and other regulated article from a place outside India either by sea, land, air or across any customs frontier.

\section{Import permit}

Official document authorizing importation of a commodity or of a biological control agent in accordance with specified phytosanitary requirements.

\section{Inspection}

Official visual examination of plants, plant products or other regulated articles to determine if pests are present and/ or to determine compliance with phytosanitary regulations.

\section{Inspection authority}

An officer of the Directorate of Plant Protection, Quarantine and Storage duly authorized by the Plant Protection Adviser for the purpose of approval and certification of Post-Entry Quarantine facilities and inspection of growing plants.

\section{Inspector}

A trained technical staff assigned with the responsibility of inspection/sampling of consignments of plants/plant products and other regulated articles for phytosanitary certification or a person authorised by the Dte of PPQS (NPPO) to discharge its functions.

\section{IPPC}

International Plant Protection Convention, as deposited in 1951 with FAO in Rome and as subsequently amended.

\section{International Standard for phytosanitary measures (ISPM)}

An international standard adopted by the conference of FAO, the interim commission for Phytosanitary on phytosanitary measures or the commission on phytosanitary measures established Measures (ISPM) under IPPC.

\section{Issuing authority}

Any officer notified by the Government of India in the Gazette, for the purpose of issuance of Plant quarantine clearance.

\section{National Plant Protection Organization (NPPO)}

Official service established by a government to discharge the functions specified by the IPPC.

\section{Notification}

A notification published in the official Gazette and the expression "notifies" shall be construed accordingly.

\section{NSPM}

National standard for phytosanitary measures established by DE of PPQS.

\section{Packing material}

Any kind of material of plant origin used for packing of goods. 


\section{Pest}

Any species, strain or biotype of plant, or pathogenic agent, injurious to plants or plant products.

\section{Plant protection adviser}

The Plant Protection Adviser, Directorate of Plant Protection, Quarantine and Storage.

\section{Point of entry}

Any sea port, airport, or land-border checkpost or rail station, river port, foreign post office, courier terminal, container freight station.

\section{Post-entry quarantine}

Growing of imported plants in confinement for a specified period of time in a glass house, screen house, poly house or any other facility, or isolated field or an off-shore island that is established in accordance with guidelines/standards and are duly approved and certified by an inspection authority notified under the PQ Order, 2003.

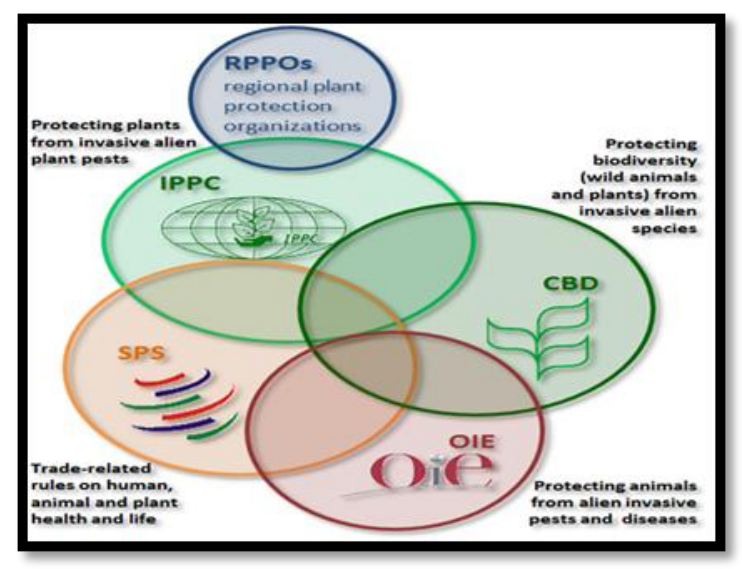

\section{Phytosanitary certificate}

Certificate patterned after the model certificates of IPPC.

\section{Plant quarantine clearance}

Use of phytosanitary procedures leading to the issue of a Plant quarantine clearance.

\section{Phytosanitary regulation}

Official rule to prevent the introduction and/ or spread of quarantine pests or to limit regulation the economic impact of regulated non-quarantine pests including establishment of procedures for phytosanitary certification.

\section{Plant products}

Unmanufactured material of plant origin (including grain) and those manufactured products that, by their nature or that of their processing, may create a risk for the spread of pests.

\section{Plants}

Living plants and parts thereof, including seeds and germplasm.

\section{Quarantine Pest}

A pest of potential economic importance to the area endangered and not yet present there, or present but not widely distributed and being officially controlled.

\section{Regulated article}

Any plant, plant product, storage place, packaging, conveyance container, soil and any other organism, object or material capable of harbouring or spread of pests deemed to require phytosanitary measures, particularly, where international transportation is involved.

\section{Regulated quarantine pest}

A non quarantine pest whose presence in plants for planting affects the intended use quarantine pest of those plants with an 
economically unacceptable impact and which is therefore regulated within the territory of the importing contracting party.

\section{Seeds}

Seeds for planting or intended for planting and not for consumption or processing.

\section{Soil}

Earth, sand, clay, silt, loam, compost, manure, peat or sphagnum moss, litter, leaf waste or any organic media that support plant life and shall include ship ballast or any organic medium used for growing plants.

\section{Stored product}

Un-manufactured plant product intended for consumption or processing stored in a dried form.

\section{Treatment}

Official procedure for the killing, inactivation, or removal of pests or for rendering pests infertile or for devitalization.

\section{Visual examination}

The physical examination of plants, plant products, or other regulated articles using the unaided eye, lens, stereoscope or microscope to detect pests or contaminants without testing or processing.

International agencies involved in plant quarantine

WTO (World Trade Organization)

IPPC (International Plant Protection Convention)

RPPO (Regional Plant Protection Organization)

APPPC (Asia and Pacific Plant Protection Commission)
PRA (Pest Risk Analysis)

(Lopian and Stephen, 2012)

\section{World Trade Organization}

An organization which was established to set and enforce rules for international trade and to provide a forum for negotiating and monitoring further trade liberalization. The headquater of WTO is at Geneva, Switzerland. SPS (sanitary and phytosanitary agreement) agreement comes into force with establishment of WTO on $1^{\text {st }}$ January, 1995. The main objective of SPS (Sanitary and Phytosanitary agreement) agreement are: (1) Protect human, animal or plant life or health in the territories of the Parties while facilitating and expanding trade by utilising a variety of means to address and seek to resolve sanitary and phytosanitary issues.(2) reinforce and build on the SPS Agreement. (3) strengthen communication, consultation and cooperation between the Parties, and particularly between the Parties' competent authorities and primary representatives.(4)ensure that sanitary or phytosanitary measures implemented by a Party do not create unjustified obstacles to trade.(5)enhance transparency in and understanding of the application of each Party's sanitary and phytosanitary measures. (6) encourage the development and adoption of international standards, guidelines and recommendations, and promote their implementation by the Parties (Anonymous, 2018)

\section{International plant protection convention}

It is the phytosanitary standard setting organization named in WTO- SPS Agreements and implemented by the FAO in 1952.The IPPC was created by member countries of the Food and Agriculture Organization of the United Nations. The IPPC places emphasis on three core areas: international standard setting, information 
exchange and capacity development for the implementation of the IPPC and associated international phytosanitary standards.

The Secretariat of the IPPC is housed at FAO headquarters in Rome, Italy, and is responsible for the coordination of core activities under the IPPC work program.

In recent years the Commission of Phytosanitary Measures of the IPPC has developed a strategic framework with the objectives of: (1) protecting sustainable agriculture and enhancing global food security through the prevention of pest spread; (2) protecting the environment, forests and biodiversity from plant pests; (3) facilitating economic and trade development through the promotion of harmonized scientifically based phytosanitary measures (Anonymous, 2018)

\section{Standards}

ISPM - 1: Principle of plant Quarantine related to international trade
ISPM - 2: Guidelines for PRA

ISPM - 7: Export certification system

ISPM - 12: Guidelines for phytosanitary certificates

\section{Regional Plant Protection Organization (RPPO)}

The RPPOs are required to cooperate with the IPPC Secretariat to achieve the objectives of the IPPC and, in turn, the CPM Secretary must convene regular technical consultations for RPPOs, promote ISPMs and encourage inter-regional cooperation. RPPOs now cover most areas of the world and all countries have the opportunity to become members of an RPPO. The main functions of RPPOs are to act as phytosanitary coordinators for their respective regions, to gather and disseminate information, to promote harmonization of phytosanitary regulations, to encourage the adoption of sound phytosanitary policies, and to promote the objectives of the IPPC. However, RPPOs have no legal force and have advisory powers only, although these can be strong (Ebbels, 2003).

\begin{tabular}{|l|l|l|l|l|}
\hline $\begin{array}{l}\text { Sr. } \\
\text { no. }\end{array}$ & Organization & Headquaters & Establishment & $\begin{array}{l}\text { No. } \\
\text { members }\end{array}$ \\
\hline $\mathbf{1}$ & $\begin{array}{l}\text { EPPO (European and Meditteranean } \\
\text { Plant Protection Organization) }\end{array}$ & Paris, France & 1951 & 51 \\
\hline $\mathbf{2}$ & $\begin{array}{l}\text { APPPC (Asia and Pacific Plant } \\
\text { Protection Commission) }\end{array}$ & $\begin{array}{l}\text { Bangkok, } \\
\text { Thailand }\end{array}$ & 1956 & 25 \\
\hline $\mathbf{3}$ & $\begin{array}{l}\text { NAPPO (North American Plant } \\
\text { Protection Organization) }\end{array}$ & Washington, D.C & 1976 & 3 \\
\hline $\mathbf{4}$ & $\begin{array}{l}\text { PPPO (Pacific Plant Protection } \\
\text { Organization) }\end{array}$ & Suva, Fiji & 1994 & 27 \\
\hline $\mathbf{5}$ & $\begin{array}{l}\text { NEPPO (Near East Plant Protection } \\
\text { Organization) }\end{array}$ & Morocco & 2009 & 12 \\
\hline
\end{tabular}

(Ebbels, 2003)

Asia and Pacific Plant Protection Commission

The Asia-Pacific Plant Protection Commission (APPPC) convened for the first time in 1956. The Commission administers the Regional Plant Protection Agreement for Asia and the Pacific. It reviews the plant protection situation at the national level in 
member countries, and also at the regional level. Coordinating and promoting development of regional plant protection systems, assisting member countries to develop effective plant protection regimes, setting standards for phytosanitary measures, and facilitating information sharing are among its key objectives. A total of 25 countries are members and the APPPC meets at least once every two years. APPPC helps member countries analyze risks to their national plant resources and use science-based measures to safeguard their cultivated and wild plants. The Commission helps member countries improve their capacity for pest surveillance, pest risk analysis, pest risk management through systems approaches, and implementation of regional and international standards for phytosanitary measures. It helps with the management of outbreaks of invasive species to promote safe agricultural trade (Anonymous, 2006)

\section{Pest risk analysis}

It is a Process of investigation, evaluation of information and decision making with respect to a certain pest, that starts once it is known or determined that this pest is quarantine pest (FAO, 1995). Main Aim of PRA is to estimate the likelihood of entry, establishment, spread of pest and its impact and to justify Phytosanitary measures on traded plant products.The Central and the state government to prevent the introduction and spread of dangerous pests and pathogens in view of various rise in the significant of import and export of the plant commodities during the recent years, the current plant quarantine procedure seem to be far from being satisfactorily equipped. To cope with these difficulties, there hamper free market accessibility to the plant commodities and the quarantine should be based on the PRA6. Risk can be defined as expected magnitude of loss. Analysis of pest risk while introducing seeds planting materials is essential to determine the potential of a pest to cause damage. In common, risks are more with the introduction vegetative propagules than true seed. Further, pathogens risks like viruses, downy mildews, smuts and many bacteria carried inside the seed without any external symptoms etc. (Gupta and Khetarpal, 2004;Neergaard, 1977b).When vegetative propagules are introduced, rooted plants, and other underground plant parts like rhizomes, suckers, runners, etc. carry higher risks than bud wood, scions and un rooted cuttings.(Chand et al.,2017)

In any case, bulk introductions are always risky as thorough examination and treatment in such cases is very difficult and planting area is far too large to prevent the establishment and spread of the introduced pest/disease. Based on these factors, plant quarantine regulates the introductions as follows:

1. Complete embargo/prohibition: When the pest risk is very high, the safeguards available in the country are not adequate and, therefore, import is prohibited.

2. Post-entry quarantine: The risk is very high but adequate safeguards in the form of post-entry isolation growing facilities are available.

3. Restricted: Pest risk is not high and import permit is required stipulating conditions for entry, inspection and treatment.

4. Unrestricted: Import permit is not required, and material may enter without restriction. While formulating quarantine regulations, local conditions like crop spectrum and environmental conditions are also to be considered. Since quarantine regulations are designed to break the life cycle of the pest/pathogen involved, the presence of 
alternate or collateral hosts in the country of import and their introduction should also be taken into account.

\section{National Agencies involved in Plant Quarantine}

Directorate of Plant Protection, Quarantine and Storage, Faridabad (NPPO)

National Bureau of Plant Genetic Resources (NBPGR), New Delhi

Crop Specific Research Institutes of Indian Council of Agricultural Research (ICAR)

Head of Plant Pathology Division of State Agricultural Universities (SAU)

State Agricultural and Horticultural Departments

Plant quarantine activities in India are carried out under the Destructive Insects and Pests Act (DIP Act) of 1914, and the rules and regulations framed from time to time there under by the Govt. of India. Seed was not covered under the DIP Act until 1984, when the Govt. of India brought forward a comprehensive Plants, Fruits and Seeds (Regulation of Import into India) Order, 1984'which came into force in June1985.Most of the plant material enters in the country through air cargo or air mail parcels. The New Seed Policy now permits private enterprises to introduce more material in certain cases under Open General Licence. Mass consignments for consumption or sowing are brought by ships, and small research consignments through air freight or by post, a variety of research institutes under the Indian Council of Agricultural Research (ICAR) and the Council of Scientific\& Industrial Research (CSIR) systems, agricultural universities, state departments of agriculture and the private individuals/agencies are the ultimate users of the introduced germplasm material in crop improvement programmes. The customs, postal, International Airport Authority and Port Authority of India should ensure that the consignments/post parcels containing seeds/planting materials are cleared quickly and are sent compulsorily to the plant quarantine services. The consignments should never be released directly to the users. All international airports/seaports/international post offices should have plant quarantine counters along with the customs counters: Various research institutes and agricultural universities can also contribute a great deal in this respect. The users of the introduced material, whether they are from the research institutes, universities, agriculture departments or private individuals/agencies, could also contribute a lot in the smooth flow of planting material. They should requirement for import permit phytosanitary certificates (Chand et al., 2017)

\section{Directorate of Plant Protection, Quarantine and Storage (NPPO)}

Directorate of Plant Protection Quarantine \& Storage was established in the year 1946 on the recommendation of Woodhead Commission as an apex organization for advising the Government of India and state governments on all the matter related to Plant Protection. The Directorate is headed by Plant Protection adviser. Plant Protection strategy and activities have significant importance in the overall crop production programmes for sustainable agriculture. Plant protection activities encompasses activities aimed to minimizing crop losses due to pests through integrated pest management, plant quarantine, regulation of pesticides, locust warning \& control and training in desert areas besides training and capacity building in plant protection. It is an attached Office of Ministry of Agriculture and Farmers Welfare. The main objective of Directorate of Plant Protection, Quarantine \& Storage are: (1) To popularize adoption of integrated pest management (IPM) through training and demonstration in crops inter-alia promotion of 
biological control approaches in crop protection technology. (2) To ensure availability of safer and effective pesticides through regulatory measures under the Insecticides Act, 1968. (3) To prevent introduction of exotic pests inimical to Indian agriculture by implementation of Destructive Insects and Pests Act, 1914 supported by Plant Quarantine Order (Regulation of Import into India), 2003. (4) To advise and assist the union government on all matters including international obligations related to plant protection. (5) To keep watch and control over locust in scheduled desert area. (6) Human resource development in plant protection technology. (7) Monitoring pesticides' residues at national level (Anonymous, 2018)

\section{National Bureau of Plant Genetic Resources (NBPGR)}

Plant genetic resources for food and agriculture means any genetic material of plant origin of actual or potential value for food and agriculture. Genetic material means any material of plant origin, including reproductive and vegetative propagating material, containing functional units of heredity and Recognized as a natural resource similar to mineral, oil, soil and water. Mandate of NBPGR is the acquisition and management of indigenous and exotic plant genetic resources for food and agriculture, and to carry out related research and human resource development, for sustainable growth of agriculture. The main Objectives of National Bureau of Plant Genetic Resources (NBPGR) are: (1) To plan, organize, conduct and coordinate exploration and collection of indigenous and exotic plant genetic resources .(2)To undertake introduction, exchange and quarantine of plant genetic resources. (3) To characterize, evaluate, document and conserve crop genetic resources and promote their use, in collaboration with other national organizations. (4)To develop information network on plant genetic resources. (5)To conduct research, undertake teaching and training, develop guidelines and create public awareness on plant genetic resources (Singh, 2018).

\section{Crop Specific Research Institutes of Indian Council of Agricultural Research (ICAR)}

After inspection of germplasm of specific crops, planting material will be further send to their specific research institutes for inspection.

\begin{tabular}{|c|c|c|c|}
\hline \multicolumn{2}{|c|}{ Institutes } & \multirow{2}{*}{. } & \multirow{2}{*}{$\begin{array}{l}\text { Headquaters } \\
\text { Shimla }\end{array}$} \\
\hline - & TCAR-Cientral Potato Research Institute. & & \\
\hline - & ICAR-Central Rice Research Institute & - & Cuttack \\
\hline - & ICAR-Indian Institute of Vegetable Research & ' & Varanasi \\
\hline - & ICAR-Indian Institute of Maize Research & - & New Delhi \\
\hline - & ICAR-Central Institute of Temperate Horticulture & - & Srinagar \\
\hline - & Central Research Institute for Jute \& Allied Fibres & - & West Bengal \\
\hline - & Central Tobacco Research Institute (CTRI) & - & Andhra Pradesh \\
\hline & Indian Institute of Pul ses Research (IIPR) & - & Kanpur \\
\hline
\end{tabular}




\title{
Phytosanitary Requirements for a Plant Quarantine Programme
}

\author{
General procedure for export
}

\section{Export flowchart}

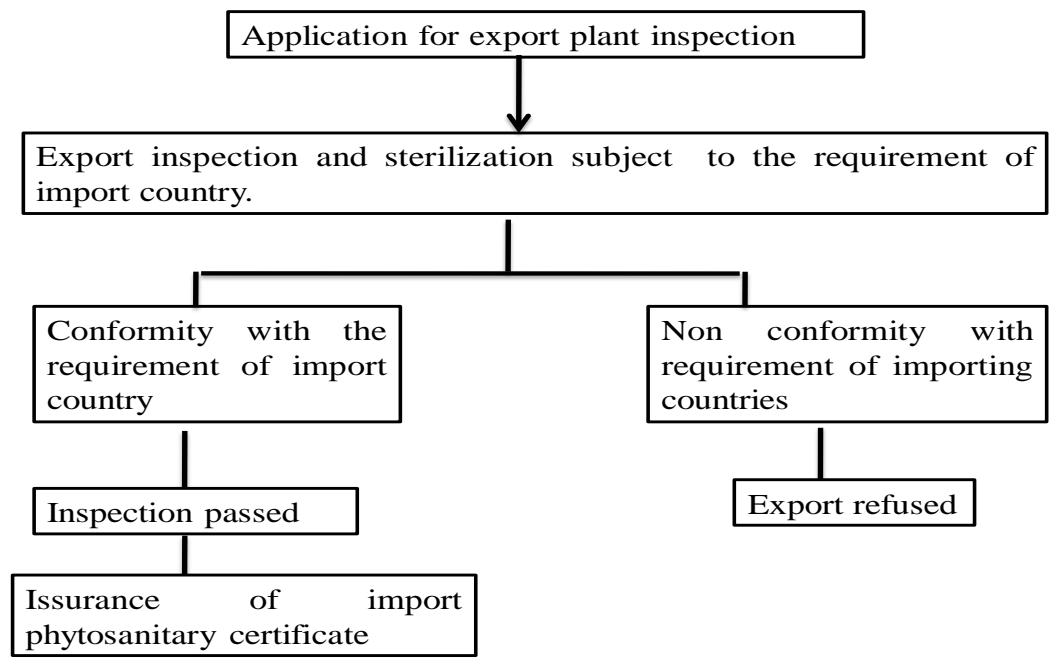

\section{Document issue and revision}

The document copy holders are responsible for ensuring all sections of document are at the correct issue status prior to use. The document approval authority as evidenced by signature/date/stamp of approving authority and document issuing authority as evidence by signature/date/stamp of issuing authority will be placed on title page and approval of revision section indicated against the revision number in the issue. The document distribution and subsequent revisions distribution are controlled and issued by the Directorate of Plant Protection Quarantine and Storage, Faridabad. This document is issued to all those notified Inspection Authorities (SAUs/ ICAR Institutes).

The purpose of this document is to facilitate adoption of standard operating procedures by all the inspection authorities notified by the Ministry of Agriculture (Department of Agriculture \& Cooperation)/PQOs (with PEQ responsibilities) for undertaking certification of postentry quarantine inspection facilities as well as conducting postentry quarantine inspection of growing plants and other regulated articles under the supervision of concerned inspection authority/ PQOs (with PEQ responsibilities) in accordance with phytosanitary requirements specified under the Plant Quarantine (Regulation of Import into India) Order, 2003 and amendments issued there under to prevent the introduction and spread of destructive pests that affects plants and other regulated articles such as biological control agents and beneficial organisms.

\section{Sanitary and phytosanitary measures}

Sanitary and phytosanitary measures are various regulations imposed by government or applied by industries to ensure

Food safety of both raw and processed Protect plant and animal health

\section{Phytosanitary certificates}

These are documents issued by an official of an exporting country, or country of re-export, attesting to the freedom from pests and 
admissibility into the destination country for specific plants or plant products.

\section{Requirements for phytosanitary certificates}

\section{General considerations}

Article V.2a of the IPPC (1997) states that: "Inspection and other related activities leading to issuance of phytosanitary certificates shall be carried out only by or under the authority of the official national plant protection organization. The issuance of phytosanitary certificates shall be carried out by public officers who are technically qualified and duly authorized by the official national plant protection organization to act on its behalf and under its control with such knowledge and information available to those officers that the authorities of importing contracting parties may accept the phytosanitary certificates with confidence as dependable documents."

\section{Purpose of phytosaniatry certificates}

Phytosanitary certificates are issued to indicate that consignments of plants, plant products or other regulated articles meet specified phytosanitary import requirements and are in conformity with the certifying statement of the appropriate model certificate. Model certificates provide a standard wording and format that should be followed for the preparation of official phytosanitary certificates. This is necessary to ensure the validity of the documents, that they are easily recognized, and that essential information is reported. Importing countries should only require phytosanitary certificates for regulated articles. These include commodities such as plants, bulbs and tubers, or seeds for propagation, fruits and vegetables, cut flowers and branches, grain, and growing medium. Phytosanitary certificates may also be used for certain plant products that have been processed where such products, by their nature or that of their processing, have a potential for introducing regulated pests (e.g. wood, cotton).

A phytosanitary certificate may also be required for other regulated articles where phytosanitary measures are technically justified (e.g. empty containers, vehicles, and organisms). Importing countries should not require phytosanitary certificates for plant products that have been processed in such a way that they have no potential for introducing regulated pests, or for other articles that do not require phytosanitary measures. NPPOs should agree bilaterally when there are differences between the views of the importing country and exporting country regarding the justification for requiring a phytosanitary certificate. Changes regarding the requirement for a phytosanitary certificate should respect the principles of transparency and non-discrimination.

\section{Mode of issue}

The phytosanitary certificate is an original document, or under specific circumstances is a certified copy issued by the NPPO, that accompanies the consignment and is presented to the relevant officials upon arrival in the importing country.

Alternatively, electronic certification may be used provided that: (1) the mode of issue and security is acceptable by the importing countries (2)the information provided is consistent with the appropriate model(s) (3) the intent of certification under the IPPC is realized (4) the identity of the issuing authority can be adequately established.

\section{Attachments}

Official attachments to the phytosanitary certificate should be limited to those instances where the information required to complete 
the certificate exceeds the available space on the certificate. The phytosanitary certificate should indicate, in the appropriate section, that the information belonging in that section is contained in the attachment. The attachment should not contain any information that would not be put on the phytosanitary certificate itself, had there been enough space.

\section{Unacceptable certificates}

Importing countries should not accept certificates that they determine to be invalid or fraudulent. The issuing authorities should be notified as soon as possible regarding unacceptable or suspect documents (ISPM No. 13: Guidelines for the notification of noncompliance and emergency action). The NPPO of the exporting country should take corrective action when necessary and maintain systems for vigilance and security to ensure that a high level of confidence is associated with phytosanitary certificates issued by that authority.
Requirements made by importing countries with respect to preparation and issue of phytosanitary certificates

Importing countries frequently specify requirements that should be observed with respect to the preparation and issue of phytosanitary certificates. They commonly include: (1) language (countries may require that certificates be completed in a specific language or one of a list of languages. (2) countries are encouraged to include one of the official languages of FAO) (3) period of validity (importing countries may specify the period of time allowed for issue following inspection and/or treatment, dispatch of the consignment from the country of origin following issue, and validity of certificate) (4) completion (countries may require that the certificate is completed by typing, or in handwritten legible capital letters) (5) units (countries may require that the description of the consignment and quantities (Anonymous, 2017)

\section{General procedure for import}

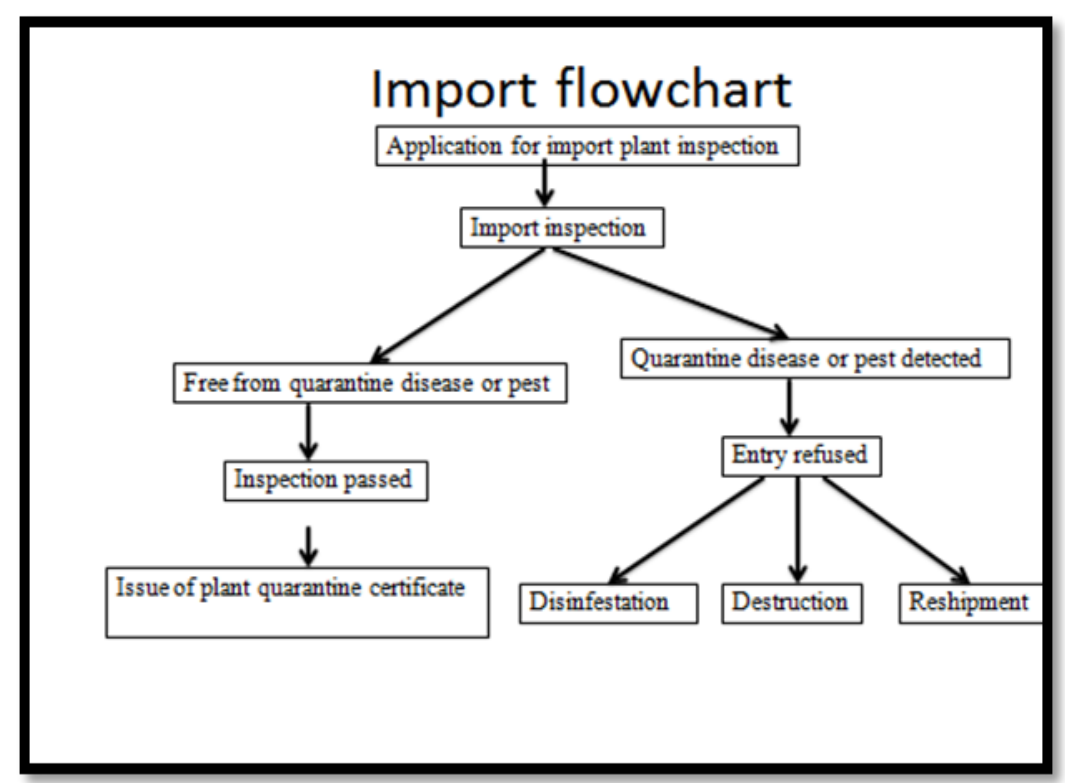




\section{Declaration, documents submission}

The importer or his authorized agent will apply in prescribed format along with attached documents (diagrammatic design of the facility/SOPs) to the concerned Inspection Authority (i.e. SAUs/ICAR Institutes) for certification of PEQ facility for growing imported plants and plant material and other regulated articles under confinement sufficiently in advance of import. The technical staff attached to the concerned inspection authority will receive the application and issue an acknowledgement slip.

\section{Registration of application}

The technical staff will register the correct and complete application and assign a registration number and record the particulars in a register (Annexure-2B) maintained by the inspection authorities for certification of PEQ facilities and submit the same to the concerned inspection authority. There are about 75 Notified point of entry at various seaports (42), Airports (19), Land frontiers (14), 65 inland container depots, 11 foreign post offices.

\section{Commodities inspection}

Preliminary/ general inspection involve inspecting outside commodities, packages, means of transport and slits to collect insect pest flying, creeping or clinging on commodities. In terms of regulated or unknown disease is not detected during inspection, the plant quarantine officer shall issue the phytosanitary certificate for import accompanied with consignments. When detected, Phytosanitary measures shall be applied depending on pests, commodities character or other specific conditions, include fumigation and destruction of insect-pest and diseases.

\section{Inspection of seed plant or benefit organisms}

All commodities must be moved to isolating areas for inspection and supervision by post entry plant quarantine office, including (1) Growing, raising of imported seed plants. (2)
Supervising, detecting latent pests on seed plants (3) Assessing, verifying and considering benefit organisms in accordance with standard. (4) Issuing phytosanitary certificate for post entry or applying phytosanitary measures. (5) Seed plant provided in the list of plants allowed of production or trade. (6) On the basis of phytosanitary notification, pest or disease status in growing areas will be inspected. (7) Notification of non-compliance shall be sent to owner or relavent organizations. (8) Phytosanitary treatment will be applied and outbreak of pest is also promulgated. Regulated articles subject to provisional import and then re-export, provisional export and then imported; tranported from border gate to border gate, bonded warehouses must be complied with phytosanitary procedure for import.

In conclusion, world over, countries have started cooperative efforts internationally in managing pest risk with the aim to prevent the introduction and spread of important pests. At the same time, countries began to adopt laws and regulations at the national level to protect themselves from new pests. Recently, under International treaties, the SPS Agreement and the IPPC have been adopted to provide a framework for how countries should implement national laws and regulations related to managing the risks associated with foreign pests. Phytosanitary measures have become the basis for national laws and regulations aimed at preventing the introduction and spread of new pests. The PQ measures acts as an important tool in excluding pests from the crop. Effective implementation of quarantine is highly emphasized for management of pests, which in turn helps in maintaining the productivity of crops.

\section{References}

Anonymous.1995. Food and Agriculture Organization (FAO). Guidelines for PRA, ISPM No. 2. (http://www.fao.org/3/aj1302e.pdf)

Anonymous.2017. Food and Agriculture Organization (FAO). Glossary of 
Phytosanitary Terms, ISPM 5 . (http://www.fao.org/3/a-a0450e.pdf) Anonymous. 2017. Food and Agriculture Organization (FAO). Guidelines for phytosanitary certificates, ISPM No. 12.(www.fao.org/3/a-k5129e.pdf)

Anonymous. 2018. Plant Quarantine information, Govt. of India, Ministry of Agriculture, Deptt. Of Agril. and Cooperation, Directorate of Plant Protection, Quarantine and Storage, Faridabad.(http://ppqs.gov.in.) $\quad\{11.00$ AM, $2^{\text {nd }}$ December, 2018\}.

Anonymous. 2018. World trade organization (WTO). (https://www.wto.org/)

Anonymous. 2018. International Plant Protection Convention (IPPC). (https://www.ippc.int/en/.)

Atwal, A.S., and Dhaliwal, G.S.1986.Agricultural pests of south Asia and their Management. Kalayani Publishers, Ludhiana., pp. 55-69.

Chand, P., Singh, A., Vishwakarma, C., and Singh, C.K.. 2017. Plant Quarantine: An Effective approach for prevention of alien pest and disease. Bulletin of Environment, Pharmacology and Life Sciences. 6: 7-12.

Dent, D. 1991. Quarantine, Legislation and Politics. In: Insect Pest Management. CAB International., pp. 421-437.

Ebbels, D. 2003. Principles of plant quarantine and health. CABI Publications, Cambridge, UK., pp. 268.

Gupta, K.., and Khetarpal, R.K. 2004. Concept of regulation pests their risk analysis and Indian scenario. Annual Review of Plant
Pathology. 4: 409-441.

Khan, H.H., Verma, S.S., Saleem, M., Verma, S.K., Usmani, T.A., Naz, H. and Naz, A. 2017. Role of history of Plant Quarantine in India- A review. International Journal of Chemical Studies. 5(6): 2034-2037.

Khetarpal, R.K., and Gupta, K. 2005. Status of Plant Protection in India in the wake of International Agreements, Indian Journal of Plant Protection.33: 153-163.

Laxmi, R.V., Geetanjaly and Sharma, P. 2014. Plant Quarantine: An Effective Strategy of Pest Management in India. Research Journal of Agriculture and Forestry Sciences. 2(1):11-16.

Mehta, P.R., and Verma, B.K. 1968. Quarantine and Introductions. In: Plant Protection. Directorate of Extension, Ministry of food, Agriculture, Community Development and Cooperation, New Dehli. Pp.19-25.

Neergaard, P. 1977. Methods for detection of seed borne fungi and bacteria. Macmillan Press Ltd., London, UK. Pp. 3338.

Reddy, D. 2010. Applied Entomology. New Vishal Publications, New Delhi. Pp. 75.

Reddy, D.B., and Joshi, N.C. 1992. Plant Protection in India. Allied Publishers Ltd., New Delhi. Pp. 420.

Rajak, R.L., Shyam, R., Kumar, U and Chattargee, G. 1999. PRA- amilstone in plant quarantine functioning of India. Plant Protection Bulletin.51: 1-2.

Singh, K. 2018. Role of ICAR-NBPGR in PGR Management. ICAR-National Bureau of Plant Genetic Resources, New Delhi. Pp. 10.

\section{How to cite this article:}

Shivani Gupta, Shalini Verma and Rajneesh Thakur. 2019. Phytosanitary Requirement for Import of Horticulture Crops. Int.J.Curr.Microbiol.App.Sci. 8(02): 2871-2886.

doi: https://doi.org/10.20546/ijcmas.2019.802.337 